\title{
Chlorophyceae das Represas Billings (Braço Taquacetuba) e Guarapiranga, SP, Brasil ${ }^{1}$
}

\author{
LUCIANO LUNA RODRIGUES², CÉLIA LEITE SANT’ANNA²,3 e ANDREA TUCCI ${ }^{2}$
}

(recebido: 12 de fevereiro de 2009; aceito: 18 de março de 2010)

\begin{abstract}
Chlorophyceae of Billings (Taquacetuba Arm) and Guarapiranga Reservoirs, SP, Brazil). Biodiversity of Chlorophyceae in two of the greatest reservoirs from the metropolitan region of São Paulo municipality, Billings and Guarapiranga, which supply water for millions of people, was studied. The samples were collected every two months, in specific sites in both reservoirs, from January to December 2004. The samples were filtered using a plankton net (20 $\mu \mathrm{m})$ and preserved with formaldehyde. Thirty six taxa belonging to two orders, ten families and 24 genera, were identified, described and illustrated. The genus Desmodesmus presented the highest species richness (four), followed by Ankistrodesmus e Scenedesmus (three species each). Ten taxa are firstly reported to the studied reservoirs. Eight taxa were found exclusively in Guarapiranga reservoir and three only in Billings reservoir, whereas $70 \%$ of the identified taxa were common to both reservoirs. The high species richness of Chlorophyceae confirms the floristic dominance of this class in tropical and commonly eutrophyzed water bodies.
\end{abstract}

Key words - Chlorophyceae, phytoplankton, reservoirs, water supply

RESUMO - (Chlorophyceae das Represas Billings (Braço Taquacetuba) e Guarapiranga, SP, Brasil). A biodiversidade de Chlorophyceae foi estudada em duas das maiores represas da Região Metropolitana da cidade de São Paulo, Billings e Guarapiranga, que fornecem água para o abastecimento de milhões de pessoas. As coletas bimensais foram realizadas durante o período de janeiro a dezembro de 2004, em uma estação localizada próximas à captação de água da Sabesp, em cada represa. As amostras foram filtradas com rede de plâncton de $20 \mu \mathrm{m}$ de abertura de malha, preservadas em formol. Foram identificados, descritos e ilustrados 36 táxons de Chlorophyceae, distribuídos em duas ordens, dez famílias e 24 gêneros. O gênero Desmodesmus apresentou maior riqueza de espécies (quatro), seguido de Ankistrodesmus e Scenedesmus (três espécies cada). Dez táxons constituíram primeiras citações para as represas estudadas. Oito táxons ocorreram exclusivamente na represa Guarapiranga e três foram registrados exclusivamente na represa Billings, sendo que 70\% das espécies foi comum aos dois reservatórios. A elevada riqueza de espécies de clorofíceas confirma o predomínio florístico desta classe em corpos de água tropicais e, geralmente, eutrofizados.

Palavras-chave - água de abastecimento, Chlorophyceae, fitoplâncton, represas

\section{Introdução}

Represas são ecossistemas artificiais intermediários entre rios e lagos e podem assumir características ecológicas similares aos ecossistemas lóticos (quando o tempo de residência é de dias ou semanas) ou lênticos (quando o tempo de residência é de meses ou anos) (Henry et al. 1998).

A composição, estrutura e dinâmica da comunidade fitoplanctônica são influenciadas pelas características morfométricas, tempo de residência, gradientes verticais de temperatura e as diferentes alturas da captação de água. Além disso, esta comunidade é fortemente influenciada por pulsos externos sazonais de sedimentos e nutrientes (Henry et al. 1998).

Em geral, as represas no Brasil constituem um dos ecossistemas mais favoráveis para a expansão

1. Parte da Dissertação de mestrado do primeiro autor, Programa de Pós-Graduação em Botânica, Instituto de Biociências, Universidade de São Paulo, São Paulo, SP, Brasil.

2. Instituto de Botânica, Núcleo de Pesquisa em Ficologia, Caixa Postal 3005, 01031-970 São Paulo, SP, Brasil.

3. Autor para correspondência: celialsant@yahoo.com.br das florações de algas e cianobactérias, pois são comumente rasas e facilmente eutrofizadas (Sant'Anna et al. 2008). Dentro deste contexto, a comunidade fitoplanctônica responde rapidamente às alterações ambientais decorrentes da interferência antrópica ou natural, alterando sua composição, estrutura e taxa de crescimento (Carvalho 2003).

As represas Billings e Guarapiranga são responsáveis pelo fornecimento de água para grande parte da região metropolitana de São Paulo (RMSP), onde a Billings é a maior represa e a Guarapiranga é o segundo maior manancial do sistema de abastecimento (Cetesb 2002, Isa 2006). A partir do ano 2000, em virtude da deficiência de água para o abastecimento da RMSP, teve início a transposição de água do Braço Taquacetuba da Billings para a Represa Guarapiranga (Cetesb 2002, Matsuzaki 2007).

Apesar da importância dessas represas para o abastecimento público da RMSP e da importância da comunidade fitoplanctônica para o monitoramento da qualidade de suas águas, pode-se afirmar que a composição específica de espécies desta comunidade continua ainda muito pouco conhecida. A maioria dos estudos realizados nesses dois ambientes foi de cunho limnológico ou 
sanitário e não taxonômico, o que contribuiu para o pouco conhecimento sobre a biodiversidade da comunidade fitoplanctônica dos mesmos.

A classe Chlorophyceae, principalmente devido a representatividade da ordem Chlorococcales, é o grupo mais diversificado quanto à riqueza de táxons em águas continentais brasileiras e vários trabalhos confirmam o elevado número de táxons dessa classe em relação às demais, especilamente em sistemas tropicais eutrofizados, conforme já comentado por Tucci et al. (2006).

Os trabalhos que mencionam a ocorrência das clorofíceas na represa Billings são: Palmer (1960) que apresentou uma listagem de táxons frequentes, dentre eles gêneros de clorofíceas. Xavier (1979) verificou que as Chlorococcales apresentaram o maior número de espécies em comparação aos outros grupos de algas. Sant'Anna (1984) estudou as Chlorococcales do Estado de São Paulo e descreveu e ilustrou vários táxons encontrados no Braço do Rio Grande. Xavier (1996) identificou, descreveu e ilustrou 28 táxons de Chlorophyceae. Carvalho (2003) estudou a comunidade fitoplanctônica como instrumento de biomonitoramento em seis represas do Estado de São Paulo e, para a Represa Billings, a comunidade fitoplanctônica foi constituída por 154 táxons, dos quais 43\% são de clorofíceas.

Para a Represa Guarapiranga, os trabalhos sobre o fitoplâncton são ainda mais escassos: Kleerekoper (1937) fez o primeiro levantamento taxonômico do fitoplâncton da Represa Santo Amaro (atual Guarapiranga) e duas clorofíceas foram mencionadas, Ankistrodesmus falcatus (Corda) Ralfs e Scenedesmus bijuga (Turpin) Lagerheim. Kleerekoper (1939) também foi pioneiro no estudo limnológico da Represa Santo Amaro, durante os anos de 1936 e 1938, onde foram coletadas quinzenalmente amostras de doze pontos da represa. Este autor organizou uma lista com os táxons mais frequentemente encontrados, porém nenhum deles foi descrito ou ilustrado. Palmer (1960) analisou amostras coletadas em vários pontos da represa e listou os principais táxons encontrados, dentre eles a clorofícea Botryococcus. Rocha (1976) estudou a limnologia, os aspectos ecológico-sanitários e a macrofauna bentônica da represa, além de apresentar uma listagem de táxons referentes à comunidade fitoplanctônica. Beyruth (1996) registrou 240 táxons, sendo 106 de Chlorophyceae (44\%). Dentre as clorofíceas, as ordens Chlorococcales e Zygnematales apresentaram a maior contribuição em número de táxons, sendo Dictyosphaerium ehrenbergianum Näegeli a espécie que mais se destacou na represa em densidade e biomassa.

Considerando a importância das represas Billings e Guarapiranga para o abastecimento de milhões de pessoas e de centenas de indústrias na RMSP, este trabalho tem como objetivo o conhecimento da biodiversidade de Chlorophyceae planctônicas dessas represas, visando contribuir com o monitoramento da qualidade de suas águas.

\section{Material e métodos}

A Represa Billings está localizada entre as coordenadas $23^{\circ} 47^{\prime}$ S e $46^{\circ} 40^{\prime} \mathrm{W}$, com área aproximada de $120 \mathrm{~km}$, profundidade máxima de 18 metros e tempo de retenção de 720 dias (Gemelgo et al. 2008). Apresenta formato complexo, dendrítico, constituído de um corpo central alongado e estreito, com oito braços laterais (Cetesb 2002, Isa 2006).

A Represa do Guarapiranga está localizada a $23^{\circ} 43^{\prime} \mathrm{S}$ e $46^{\circ} 32^{\prime}$ W; possui área inundada de $33 \mathrm{~km}^{2}$, profundidade máxima de 13 metros e tempo de retenção de 185 dias, fornecendo 11 mil litros de água por segundo para cerca de 3,7 milhões de pessoas. Possui morfologia do tipo dendrítica, estreita e alongada, o que acentua a influência do uso e ocupação do solo em sua bacia hidrográfica (Cetesb 2002, Isa 2006).

Amostras de água (10 litros) foram coletadas a cada dois meses na subsuperfície da coluna de água durante o período de janeiro a novembro de 2004. A estação de coleta na Represa Billings (Braço Taquacetuba) localiza-se próximo à captação de água para a transposição de água para a Guarapiranga. Na Represa Guarapiranga, as coletas foram feitas próximas ao local de captação de água da Sabesp para o abastecimento público. Para concentrar as amostras de 10 litros, estas foram filtradas com rede de plâncton, com abertura de malha de $20 \mu \mathrm{m}$ e fixadas em formol $4 \%$.

O estudo do material foi feito ao microscópio Zeiss Axioplan com câmara clara, retículo micrometrado e máquina fotográfica acoplados. Para cada amostra foram analisadas no mínimo 20 lâminas para a identificação dos táxons. Sempre que possível material vivo também foi examinado. A identificação taxonômica baseou-se em características morfométricas de amostras populacionais (no mínimo 30 indivíduos de cada táxon), exceto nos casos dos táxons raros. Para evidenciar a presença de mucilagem usou-se tinta nanquim e para confirmar a presença de pirenóide foi utilizado solução de lugol.

Os sistemas de classificação adotados foram os de Komárek \& Fott (1983), para as Chlorococcales, e Huber-Pestalozzi (1961), para as Volvocales. As amostras foram depositadas na coleção de algas do Herbário Maria Eneida P. Kauffman Fidalgo (SP) do Instituto de Botânica.

\section{Resultados e discussão}

Considerando as duas represas estudadas, foram identificados 36 táxons de clorofíceas distribuídos em duas ordens, dez famílias e 24 gêneros. Deste total de táxons, 10 constituem primeiras referências para as represas. 


\section{CHLOROCOCCALES}

\section{BOTRYOCOCCACEAE}

\section{Botryococcus Kützing}

Chave para identificação dos táxons encontrados nas represas Billings e Guarapiranga:

1. Colônias com prolongamentos mucilaginosos Botryococcus terribilis

1. Colônias sem prolongamentos mucilaginosos Botryococcus neglectus

Botryococcus neglectus (West \& G. S.West) Komárek \& Marvan, Arch. Protistenkd. 141: 92. 1992. 三Ineffigiata neglecta West \& G. S.West, J. R. Microsc. Soc. 17:231. 1897.

Figura 1

Colônias compactas, arredondadas, irregulares, compostas de subcolônias, 36,0-41,0 $\mu$ m compr. Células obovóides, densamente e radialmente arranjadas na periferia da colônia, 4,5-5,5 $\mu \mathrm{m}$ compr., 2,5-3,0 $\mu \mathrm{m}$ larg. Ápices celulares totalmente imersos na mucilagem colonial. Cloroplasto único, parietal, sem pirenóide.

Material examinado: BRASIL. São PAULO: São Paulo, Represa Guarapiranga, 18-XI-2004, Cetesb s.n. (SP399771); Represa Billings (Taquacetuba), 5-V-2004, Cetesb s.n. (SP399773).

Referências do táxon para as represas estudadas: Represa Guarapiranga (Beyruth 1996).

Segundo Komárek \& Marvan (1992), Botryococcus neglectus é frequentemente identificado como $B$. braunii Kützing devido à similaridade morfológica entre os dois táxons. Porém, B. braunii apresenta dimensões celulares maiores (6,0-14,0 $\mu \mathrm{m}$ compr.; 4,0-11,0 $\mu \mathrm{m}$ larg.) e os ápices celulares não envolvidos pela mucilagem colonial estratificada.

Botryococcus terribilis Komárek \& Marvan, Arch. Protistenkd. 141: 92. 1992.

Figura 2

Colônias compactas, arredondadas, irregulares, compostas de subcolônias, 44,0-52,0 $\mu \mathrm{m}$ compr. Mucilagem colonial com prolongamentos irregulares, 2,0-4,5 $\mu \mathrm{m}$ compr. Células obovóides, densamente e radialmente arranjadas na periferia da colônia, 7,5-9,0 $\mu \mathrm{m}$ compr., 4,0-5,0 $\mu \mathrm{m}$ larg. Ápices celulares totalmente imersos na mucilagem colonial. Cloroplasto único, parietal, sem pirenóide.

Material examinado: BRASIL. São PaUlo: São Paulo, Represa Billings (Taquacetuba), 22-IX-2004, Cetesb s.n. (SP399774).

Referências do táxon para as represas estudadas: Represa Billings (Carvalho 2003).
Botryococcus terribilis é morfologicamente muito semelhante a $B$. neglectus, da qual difere pela presença de prolongamentos mucilaginosos na superfície da colônia, que é característica diagnóstica de $B$. terribilis.

\section{Dichotomococcus Korshikov}

Dichotomococcus curvatus Korshikov, Uchen. Zap. Gork. Univ. 9:109-111. 1939.

Figura 3

Colônias irregulares, formadas por grupos de 2 célulasunidas por pedúnculos mucilaginosos dicotômicos, inconspícuos. Mucilagem colonial hialina. Células lanceoladas, levemente curvas, alargadas e arredondadas na base próxima ao pedúnculo, atenuadas gradualmente em direção ao ápice, 5,5-7,0 $\mu \mathrm{m}$ compr., 2,3-2,8 $\mu \mathrm{m}$ larg. Cloroplasto único, parietal, sem pirenóide.

Material examinado: BRASIL. São PAulo: São Paulo, Represa Guarapiranga, 8-I-2004, Cetesb s.n. (SP391778), 25-III-2004, Cetesb s.n. (SP391779), 18-XI-2004, Cetesb s.n. (SP399771); Represa Billings (Taquacetuba), 7-I-2004, Cetesb s.n. (SP399772).

Referências do táxon para as represas estudadas: primeira referência.

\section{Dictyosphaerium Nägeli}

Dictyosphaerium sphagnale Hindák, Biol. Prace 26 (6):54. 1980.

Figura 4

Colônias arredondadas, 35,0-55,0 $\mu \mathrm{m}$ larg., formadas por grupos de 4 células unidas por fios de mucilagem inseridos na porção basal das células. Mucilagem colonial hialina. Células adultas ovaladas, 4,5-5,5 $\mu \mathrm{m}$ compr., 3,5-4,0 $\mu \mathrm{m}$ larg. Cloroplasto único, poculiforme, com um pirenóide.

Material examinado: BRASIL. SÃo PAULO: São Paulo, Represa Guarapiranga, 8-I-2004, Cetesb s.n. (SP391778), 25-III-2004, Cetesb s.n. (SP391779), 6-V-2004, Cetesb s.n. (SP399768), 15-VII-2004, Cetesb s.n. (SP399769); Represa Billings (Taquacetuba), 5-V-2004, Cetesb s.n. (SP399773). 
Referências do táxon para as represas estudadas: primeira referência.

Dictyosphaerium sphagnale apresenta similaridade morfológica com Dictyosphaerium elegans Bachmann, sendo que a principal diferença entre os dois táxons, segundo Hindák (1980), consiste na ausência de pirenóide em $D$. elegans.

\section{CHLORELLACEAE}

\section{Ankistrodesmus Corda}

Chave para identificação dos táxons encontrados nas represas Billings e Guarapiranga:

1. Células fusiformes, retas Ankistrodesmus fusiformis

1. Células fusiformes, arcuadas ou lunadas

2. Distância entre os ápices superior a $20 \mu \mathrm{m}$ Ankistrodesmus gracilis

2. Distância entre os ápices inferior a $20 \mu \mathrm{m}$ Ankistrodesmus bibraianus

Ankistrodesmus bibraianus (Reinsch) Korshikov, Protococcineae 302. 1953. 三 Selenastrum bibraianum Reinsch, Algenfl. Franken. 64. 1867.

Figura 5

Colônias irregulares, formadas por 32 ou 64 células, unidas por suas superfícies convexas. Mucilagem colonial tênue, hialina, circundando as colônias. Células lunadas, afilando gradualmente em direção aos ápices, 9,0-14,0 $\mu \mathrm{m}$ de distância entre os ápices, 3,5-4,0 $\mu \mathrm{m}$ larg. Cloroplasto único, parietal, sem pirenóide.

Material examinado: BRASIL. SÃo PAULO: São Paulo, Represa Guarapiranga, 6-V-2004, Cetesb s.n. (SP399768), 15-VII-2004, Cetesb s.n. (SP399769).

Referências do táxon para as represas estudadas: Represa Billings (Sant’Anna 1984, Xavier 1996, Carvalho 2003); Represa Guarapiranga (Beyruth 1996).

Ankistrodesmus fusiformis Corda sensu Korshikov, Protococcineae 300. 1953.

Figura 6

Colônias formadas por 4 células, dispostas cruciada ou radialmente. Mucilagem colonial hialina, circundando as células. Células fusiformes, alongadas, retas, afilando gradualmente em direção aos ápices, apenas cruzando-se uma sobre as outras, 60,0-75,0 $\mu \mathrm{m}$ compr., 2,0-3,0 $\mu \mathrm{m}$ larg. Cloroplasto único parietal, sem pirenóide.

Material examinado: BRASIL. São PAULO: São Paulo, Represa Guarapiranga, 8-I-2004, Cetesb s.n. (SP391778), 25-III-2004, Cetesb s.n., (SP391779),
6-V-2004, Cetesb s.n. (SP399768), 15-VII-2004, Cetesb s.n. (SP399769), 23-IX-2004, Cetesb s.n. (SP399770), 18-XI-2004, Cetesb s.n. (SP399771); Represa Billings (Taquacetuba), 5-V-2004, Cetesb s.n. (SP399773).

Referências do táxon para as represas estudadas: Represa Billings (Sant'Anna 1984, Xavier 1996, Carvalho 2003); Represa Guarapiranga (Beyruth 1996).

Ankistrodesmus gracilis (Reinsch) Korshikov, Protococcineae 305. 1953. $\equiv$ Selenastrum gracile Reinsch, Algenfl. Franken. 64.1867.

Figura 7

Colônias regulares, formadas por 4 células unidas por suas superfícies convexas. Mucilagem colonial hialina, concentrada na região central da colônia. Células fusiformes, arcuadas, afilando gradualmente em direção aos ápices, 22,0-30,0 $\mu$ m de distância entre os ápices, 3,0-3,5 $\mu \mathrm{m}$ larg. Cloroplasto único, parietal, sem pirenóide.

Material examinado: BRASIL. SÃo PAULO: São Paulo, Represa Guarapiranga, 25-III-2004, Cetesb s.n. (SP391779), 6-V-2004, Cetesb s.n. (SP399768), 15-VII-2004, Cetesb s.n.(SP399769), 23-IX-2004, Cetesb s.n. (SP399770), 18-XI-2004, Cetesb s.n. (SP399771); Represa Billings (Taquacetuba), 7-I-2004, Cetesb s.n. (SP399772), 5-V-2004, Cetesb s.n. (SP399773), 22-IX-2004, Cetesb s.n. (SP399774).

Referências do táxon para as represas estudadas: Represa Billings (Carvalho 2003); Represa Guarapiranga (Beyruth 1996).

\section{Monoraphidium Komárková-Legnerová}

Chave para identificação dos táxons encontrados nas represas Billings e Guarapiranga:

1. Células fusiformes, apenas arcuadas Monoraphidium arcuatum

1. Células fusiformes, torcidas helicoidalmente Monoraphidium contortum 

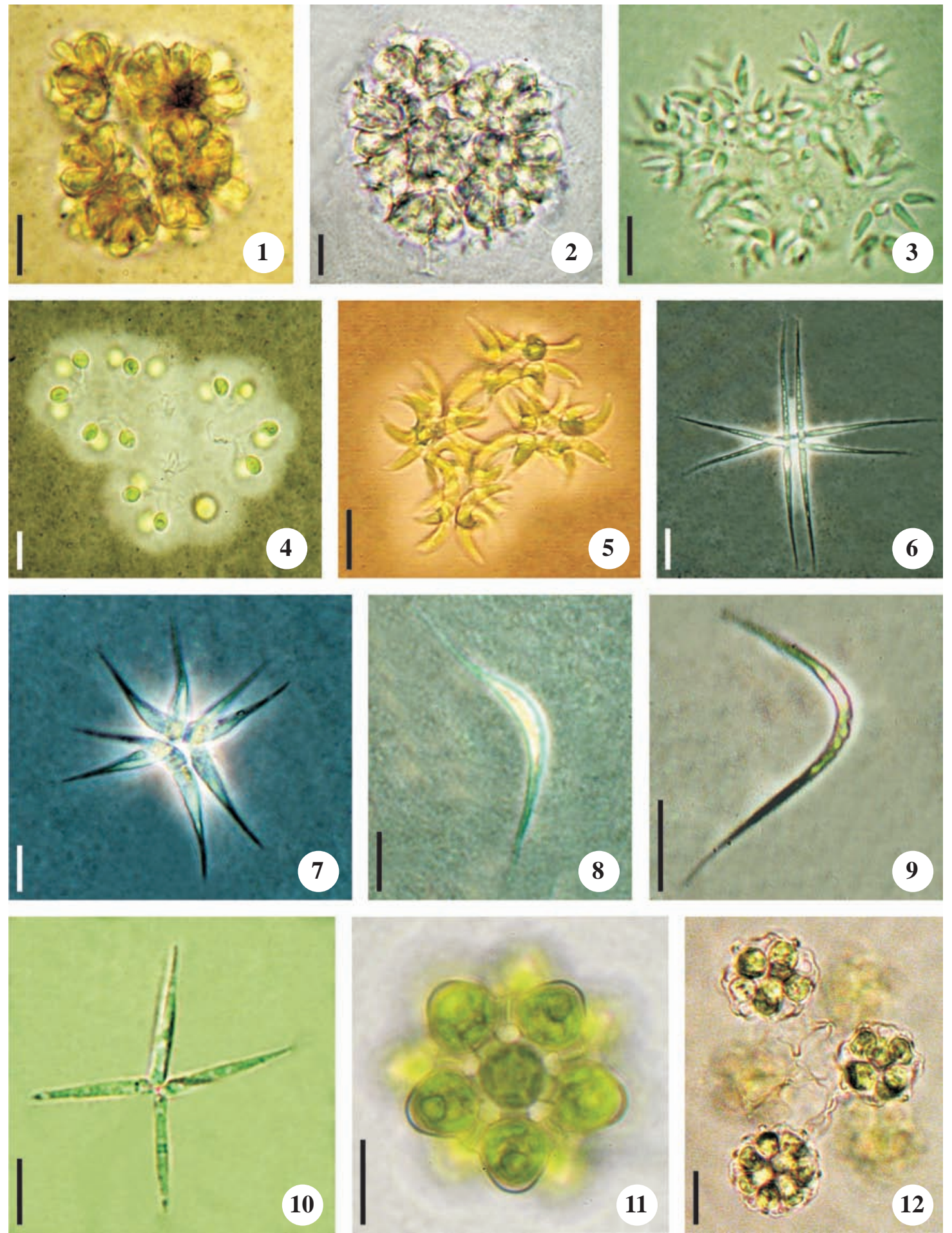

Figuras 1-12. Chlorophyceae das represas Billings e Guarapiranga. 1. Botryococcus neglectus. 2. Botryococcus terribilis. 3. Dichotomococcus curvatus. 4. Dictyosphaerium sphagnale. 5. Ankistrodesmus bibraianus. 6. Ankistrodesmus fusiformis. 7. Ankistrodesmus gracilis. 8. Monoraphidium arcuatum. 9. Monoraphidium contortum. 10. Actinastrum hantzschii var. subtile. 11. Coelastrum indicum. 12. Coelastrum reticulatum (sincenobios). Barra $=10 \mu \mathrm{m}$

Figures 1-12. Chlorophyceae of Billings and Guarapiranga Reservoirs. 1. Botryococcus neglectus. 2. Botryococcus terribilis. 3. Dictyosphaerium sphagnale. 4. Dichotomococcus curvatus. 5. Ankistrodesmus bibraianus. 6. Ankistrodesmus fusiformis. 7. Ankistrodesmus gracilis. 8. Monoraphidium arcuatum. 9. Monoraphidium contortum. 10. Actinastrum hantzschii var. subtile. 11. Coelastrum indicum. 12. Coelastrum reticulatum (syncoenobia). Bar $=10 \mu \mathrm{m}$. 
Monoraphidium arcuatum (Korshikov) Hindák, Algolog. Stud. 1:19. 1970. $\equiv$ Ankistrodesmus arcuatus Korshikov, Protococcineae 296. 1953.

Figura 8

Células solitárias, fusiformes, arcuadas, afilando gradualmente em direção aos ápices, pólos pontiagudos, 41,0-45,0 $\mu \mathrm{m}$ de distância entre os ápices, 3,0-3,5 $\mu \mathrm{m}$ larg. Cloroplasto único, parietal, com reentrância lateral, sem pirenóide.

Material examinado: BRASIL. São PAULO: São Paulo, Represa Guarapiranga, 18-XI-2004, Cetesb s.n. (SP399771).

Referências do táxon para as represas estudadas: Represa Guarapiranga (Beyruth 1996).

Monoraphidium contortum (Thuret) KomárkováLegnerová, Stud. Phycol. 104. 1969. 三Ankistrodesmus contortus Thuret, Mem. Soc. Imper. Sci. Nat. Cherbourg 4:158. 1856.

Figura 9

Células solitárias, fusiformes, helicoidais com 1 ou 1,5 voltas, afilando gradualmente em direção aos ápices, pólos pontiagudos, 19,0-25,0 $\mu \mathrm{m}$ de distância entre os ápices, 1,2-1,5 $\mu \mathrm{m}$ larg. Cloroplasto único, parietal, sem pirenóide.

Material examinado: BRASIL. São PAULO: São Paulo, Represa Guarapiranga, 25-III-2004, Cetesb s.n. (SP391779), 6-V-2004, Cetesb s.n. (SP399768),
15-VII-2004, Cetesb s.n.(SP399769), 23-IX-2004, Cetesb s.n. (SP399770), 18-XI-2004, Cetesb s.n. (SP399771); Represa Billings (Taquacetuba), 7-I-2004, Cetesb s.n. (SP399772), 5-V-2004, Cetesb s.n. (SP399773).

Referências do táxon para as represas estudadas: Represa Billings (Xavier 1996, Carvalho 2003); Represa Guarapiranga (Beyruth 1996).

\section{COELASTRACEAE}

Actinastrum Lagerheim

Actinastrum hantzschii Lagerheim var. subtile Woloszynska, Rpzpr. Spraw. Wydz. Akad. Umiej. Krakow 51: 301-302. 1911.

Figura 10

Cenóbios estrelados, formados por 4 ou 8 células, radiando de um centro comum. Mucilagem colonial ausente. Células lanceoladas, afilando gradualmente em direção ao ápice, 15,0-19,0 $\mu$ m compr., 2,0-3,0 $\mu \mathrm{m}$ larg. Cloroplasto único, parietal, pirenóide não observado.

Material examinado: BRASIL. SÃo PAULo: São Paulo, Represa Guarapiranga, 8-I-2004, Cetesb s.n. (SP391778), 25-III-2004, Cetesb s.n. (SP391779), 15-VII-2004, Cetesb s.n. (SP399769); Represa Billings (Taquacetuba), 7-I-2004, Cetesb s.n. (SP399772), 5-V-2004, Cetesb s.n. (SP399773), 30-XI-2004, Cetesb s.n. (SP399775).

Referências do táxon para as represas estudadas: primeira referência.

\section{Coelastrum Nägeli}

Chave para identificação dos táxons encontrados nas represas Billings e Guarapiranga:

1. Cenóbios estrelados; células com espessamento apical

1. Cenóbios esféricos; células sem espessamento apical .. Coelastrum indicum Coelastrum reticulatum

Coelastrum indicum Turner, Bih. Kgl. Svensk. Vetensk. Akad. Handl. 25(5): 161.1892.

Figura 11

Cenóbios estrelados, 26,0-31,0 $\mu \mathrm{m}$ diâm., formado por 16 células, espaços intercelulares presentes. Células arredondadas em vista lateral, poliédricas em vista apical, com espessamento apical na parede, 7,5-9,0 $\mu \mathrm{m}$ compr.; 6,5-8,0 $\mu \mathrm{m}$ larg.; células unidas por 5 processos de ligação, 3,0-3,2 $\mu \mathrm{m}$ compr., 1,5-1,7 $\mu \mathrm{m}$ larg. Cloroplasto único, poculiforme, com 1 pirenóide.

Material examinado: BRASIL. São PAULO: São Paulo, Represa Guarapiranga, 8-I-2004, Cetesb s.n. (SP391778), 6-V-2004, Cetesb s.n. (SP399768),
15-VII-2004, Cetesb s.n.(SP399769), 23-IX-2004, Cetesb s.n. (SP399770), 18-XI-2004, Cetesb s.n. (SP399771); Represa Billings (Taquacetuba), 7-I-2004, Cetesb s.n. (SP399772), 22-IX-2004, Cetesb s.n. (SP399774), 30-XI-2004, Cetesb s.n. (SP399775).

Referências do táxon para as represas estudadas: Represa Billings (Carvalho 2003).

Coelastrum reticulatum (Dangeard) Senn, Bot. Ztg. 57:66. 1899. $\equiv$ Hariotina reticulata Dangeard, Le Botaniste 1:163. 1889.

Figuras 12-13

Cenóbios esféricos, 18,0-28,0 $\mu \mathrm{m}$ diâm., formados por 32 células, espaços intercelulares 
presentes. Sincenóbios frequentes, unidos por cordões mucilaginosos. Células esféricas em vista apical e lateral, sem espessamento apical na parede, 6,0-8,0 $\mu$ m diâm.; células unidas por 5 processos de ligação. Cloroplasto único, poculiforme, pirenóide não observado.

Material examinado: BRASIL. São PAULO: São Paulo, Represa Guarapiranga, 6-V-2004, Cetesb s.n. (SP399768), 15-VII-2004, Cetesb s.n. (SP399769), 23-IX-2004, Cetesb s.n. (SP399770); Represa Billings (Taquacetuba), 5-V-2004, Cetesb s.n. (SP399773).

Referências do táxon para as represas estudadas: Represa Billings (Sant'Anna 1984, Xavier 1996, Carvalho 2003); Represa Guarapiranga (Beyruth 1996).

\section{GOLENKINIACEAE}

\section{Acanthosphaera Lemmermann}

Acanthosphaera zachariasi Lemmermann, Forsch. Biol. Stat. Plön. 7: 118. 1899.

Figuras 14-15

Células solitárias, esféricas, 11,0-14,0 ㅆm diâm., sem envoltório mucilaginoso. Numerosas setas, em torno de 20, distribuídas regularmente na superfície celular, bases alargadas até um quarto do seu comprimento, depois afilando gradualmente em direção ao ápice; 26,0-31,0 $\mu \mathrm{m}$ compr. Cloroplasto único, parietal, com 1 pirenóide.

Material examinado: BRASIL. São PAULo: São Paulo, Represa Guarapiranga, 8-I-2004, Cetesb s.n. (SP391778).

Referências do táxon para as represas estudadas: Represa Guarapiranga (Kleerekoper 1939).

\section{HYDRODICTYACEAE}

\section{Monactinus Corda}

Monactinus simplex (Meyen) Corda, Alm. Carlsbad 9:239. 1839. $\equiv$ Pediastrum simplex Meyen, Nova Acta Acad. Caesar. Leop. Carol. 14:772. 1829.

Figura 16

Cenóbios arredondados, 72,0-94,0 $\mu \mathrm{m}$ diâm., 16 células dispostas concentricamente, com espaços intercelulares. Células externas poligonais, 22,0-28,0 $\mu \mathrm{m}$ compr. (com processos), 8,5-10,5 $\mu \mathrm{m}$ larg., com 1 processo cônico alongado e truncado, 17,0-20,0 $\mu \mathrm{m}$ compr. Células internas triangulares, 8,0-13,0 $\mu \mathrm{m}$ compr., 6,0-11,0 $\mu \mathrm{m}$ larg. Parede celular lisa. Cloroplasto único, parietal, com 1 pirenóide excêntrico.
Material examinado: BRASIL. São PaUlo: São Paulo, Represa Guarapiranga, 8-I-2004, Cetesb s.n. (SP391778), 6-V-2004, Cetesb s.n. (SP399768), 15-VII-2004, Cetesb s.n. (SP399769); Represa Billings (Taquacetuba), 7-I-2004, Cetesb s.n. (SP399772), 5-V-2004, Cetesb s.n. (SP399773), 22-IX-2004, Cetesb s.n. (SP399774), 30-XI-2004, Cetesb s.n. (SP399775).

Referências do táxon para as represas estudadas: Represa Billings (como Pediastrum simplex Meyen: Sant'Anna 1984, Xavier 1996, Carvalho 2003).

Análises ultra-estrututrais e moleculares, baseadas principalmente nos genes 18S e 26S, demonstraram que o gênero Pediastrum não é monofilético (Buchheim et al. 2005). Assim, foi proposta a divisão desse gênero e a transferência de algumas de suas espécies para gêneros novos (Parapediastrum, Pseudopediastrum) ou gêneros já existentes (Monactinus, Stauridium) (Buchheim et al. 2005). De acordo com o Código de Nomenclatura Botânica, o clado contendo a espécie-tipo do gênero, no caso Pediastrum duplex, deve manter o nome do gênero.

Análises filogenéticas confirmaram o isolamento de Pediastrum simplex dentro do clado Pediastrum (Buchheim et al. 2005). Segundo esses mesmos autores, a morfologia de Pediastrum simplex é consistente com a descrição do gênero Monactinus feita por Corda em 1839 e, portanto, deve ser considerada uma espécie deste gênero e não mais de Pediastrum.

\section{Parapediastrum Hegewald}

Parapediastrum biradiatum (Meyen) Hegewald, J. Phycol. 41:1052. 2005. झ Pediastrum biradiatum Meyen, Nova Acta Acad. Caesar. Leop. Carol. 14:772. 1829. Figura 17

Cenóbios planos, arredondados, 26,0-34,0 ㅆm diâm., formados por 8 células dispostas concentricamente, com espaços intercelulares. Células externas poligonais, unidas somente pelas bases laterais, 8,0-9,0 $\mu \mathrm{m}$ compr. (com processos), 4,5-5,0 $\mu \mathrm{m}$ larg.; 4 processos dicotomicamente bifurcados de tamanhos similares, 2,6-2,8 $\mu \mathrm{m}$ compr. Célula interna retangular, 5,5 $\mu \mathrm{m}$ compr., 6,0 $\mu \mathrm{m}$ larg. Parede celular lisa. Cloroplasto único, parietal, com 1 pirenóide basal.

Material examinado: BRASIL. SÃo PAULO: São Paulo, Represa Guarapiranga, 8-I-2004, Cetesb s.n. (SP391778), 25-III-2004, Cetesb s.n. (SP391779); Represa Billings (Taquacetuba), 7-I-2004, Cetesb s.n. (SP399772), 5-V-2004, Cetesb s.n. (SP399773).

Referências do táxon para as represas estudadas: primeira referência. 
De acordo com dados moleculares do gene 18S, Pediastrum biradiatum constitui um táxon monofilético dentro do clado Pediastrum, tendo como grupo irmão o gênero Sorastrum. No entanto, a união desses dois gêneros não foi sustentada por características morfológica ou filogenéticas (Buchheim et al. 2005). Ainda conforme estes autores, Pediastrum biradiatum foi transferido para o novo gênero Parapediastrum, apresentando nova combinação adotada neste trabalho.

\section{Pediastrum Meyen}

Chave para identificação dos táxons encontrados nas represas Billings e Guarapiranga:

1. Células com processos menores que a largura celular Pediastrum duplex var. duplex

1. Células com processos maiores que a largura celular Pediastrum duplex var. gracilimum

Pediastrum duplex var. duplex Meyen 1829, Nova Acta Acad. Caesar. Leop. Carol. 14:772. 1829.

Figura 18

Cenóbios planos, arredondados, 62,0-72,0 $\mu$ m diâm., formados por 16 células dispostas concentricamente, com espaços intercelulares. Células externas poligonais, 14,0-16,0 $\mu \mathrm{m}$ compr. (com processos), 11,0-12,0 $\mu \mathrm{m}$ larg., unidas entre si pelas bases; 2 processos cilíndricos com ápices truncados, 7,0-7,5 $\mu \mathrm{m}$ compr. Células internas retangulares, 9,0-10,0 $\mu \mathrm{m}$ compr., 11,0-13,0 $\mu \mathrm{m}$ larg., conectadas entre si por 4 pontos. Parede celular lisa. Cloroplasto único, parietal, com 1 pirenóide basal.

Material examinado: BRASIL. SÃo PAULO: São Paulo, Represa Guarapiranga, 8-I-2004, Cetesb s.n. (SP391778), 25-III-2004, Cetesb s.n. (SP391779), 6-V-2004, Cetesb s.n. (SP399768), 15-VII-2004, Cetesb s.n. (SP399769), 23-IX-2004, Cetesb s.n. (SP399770), 18-XI-2004, Cetesb s.n. (SP399771); Represa Billings (Taquacetuba), 7-I-2004, Cetesb s.n. (SP399772), 5-V-2004, Cetesb s.n. (SP399773).

Referências do táxon para as represas estudadas: Represa Billings (Sant’Anna 1984, Xavier 1996, Carvalho 2003).

Pediastrum duplex var. gracilimun West \& G. S.West, Trans. Linn. Soc. Lond. 5:52. 1895.

Figura 19

Cenóbios planos, arredondados, 52,0-91,0 ㅆm diâm., formados por 8 ou 16 células dispostas concentricamente, com espaços intercelulares. Células externas poligonais, 16,0-21,0 $\mu$ m compr.(com processos), 10,0-11,0 $\mu$ mlarg., unidas entre si pelas bases; 2 processos cilíndricos com ápices truncados, 11,0-13,0 $\mu$ m compr. Células internas retangulares, 11,0-12,5 $\mu \mathrm{m}$ compr., 11,5-14,5 $\mu \mathrm{m}$ larg., conectadas entre si por 4 pontos. Parede celular lisa. Cloroplasto único, parietal, com 1 pirenóide basal.

Material examinado: BRASIL. SÃo PAULO: São Paulo, Represa Guarapiranga, 8-I-2004, Cetesb s.n.
(SP391778), 25-III-2004, Cetesb s.n. (SP391779), 6-V-2004, Cetesb s.n. (SP399768), 23-IX-2004, Cetesb s.n. (SP399770); Represa Billings (Taquacetuba), 5-V-2004, Cetesb s.n. (SP399773).

Referências do táxon para as represas estudadas: primeira referência.

\section{Stauridium Corda}

Stauridium tetras (Ehrenberg) Hegewald, J. Phycol. 41:1051. 2005. 三 Micrasterias tetras Ehrenberg, Infusionsthierchen 1:155. 1838.

Figura 20

Cenóbios arredondados, 22,0-28,0 ㅆm diâm., formados por 8 células arranjadas concentricamente, espaços intercelulares ausentes. Células internas e externas poligonais, 7,5-10,0 $\mu \mathrm{m}$ compr., 5,0-7,0 $\mu \mathrm{m}$ larg. Células externas com 2 processos bifurcados, 4,5-5,5 $\mu \mathrm{m}$ compr., incisão mediana até a metade do comprimento da célula. Parede celular lisa. Cloroplasto único, parietal, pirenóide não observado.

Material examinado: BRASIL. SÃo PAULO: São Paulo, Represa Guarapiranga, 25-III-2004, Cetesb s.n. (SP391779), 15-VII-2004, Cetesb s.n. (SP399769), 23-IX-2004, Cetesb s.n. (SP399770), 18-XI-2004, Cetesb s.n. (SP399771); Represa Billings (Taquacetuba), 7-I-2004, Cetesb s.n. (SP399772), 5-V-2004, Cetesb s.n., (SP399773), 22-IX-2004, Cetesb s.n. (SP399774), 30-XI-2004, Cetesb s.n. (SP399775).

Referências do táxon para as represas estudadas: Represa Billings (como Pediastrum tetras (Ehrenberg) Ralfs: Sant'Anna 1984, Xavier 1996, Carvalho 2003); Represa Guarapiranga (Beyruth 1996).

Com base em análises moleculares do gene 18S, Pediastrum tetras (Ehrenberg) Ralfs e Pediastrum privum (Printz) Hegewald constituem um grupo basal monofilético dentro do clado Pediastrum (Buchheim et al. 2005). Segundo Buchheim et al. (2005), Corda (1835) identificou dois táxons morfologicamente 

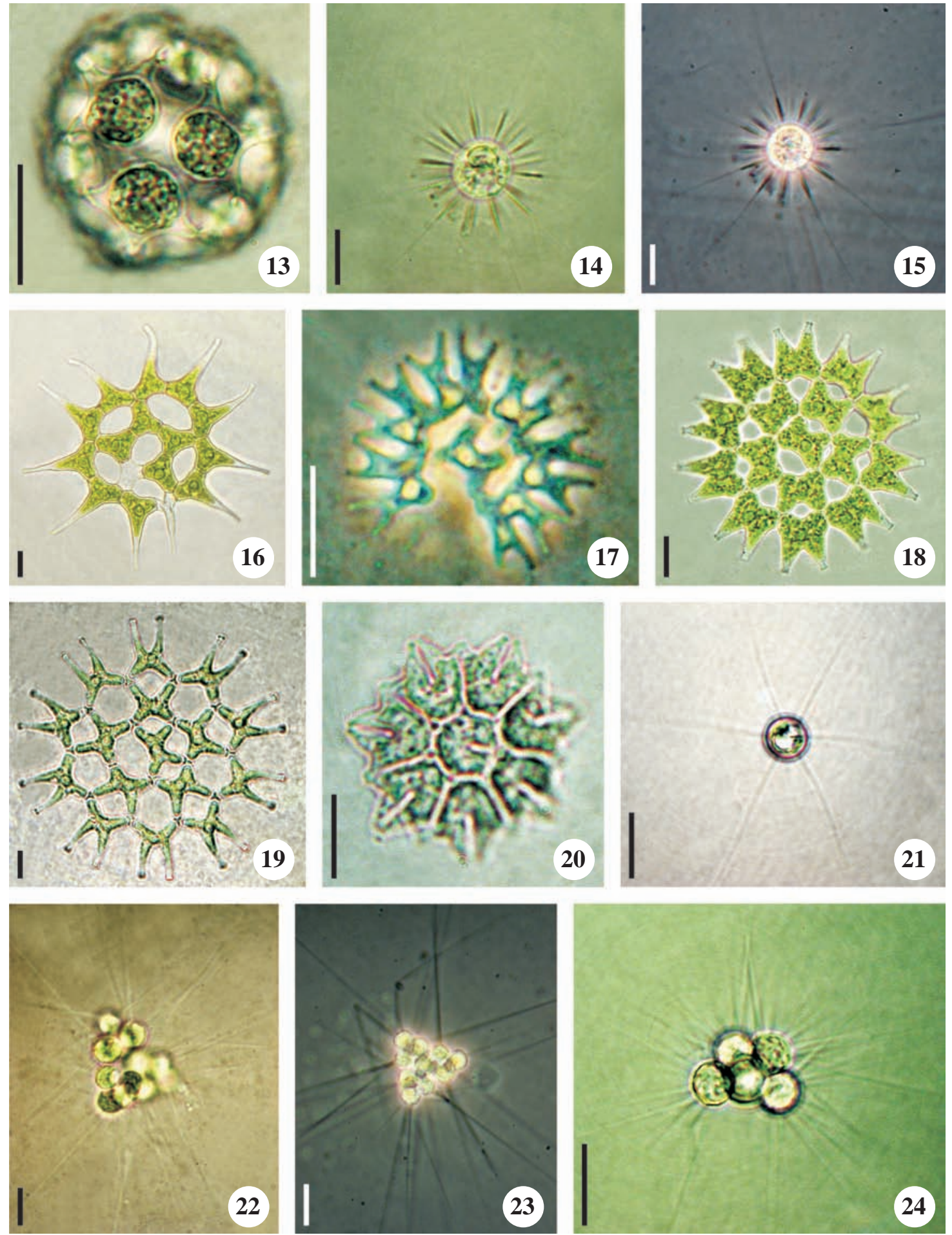

Figuras 13-24. Chlorophyceae das represas Billings e Guarapiranga. 13. Coelastrum reticulatum. 14. Acanthosphaera zachariasi. 15. Acanthosphaera zachariasi (contraste de fase). 16. Monactinus simplex. 17. Parapediastrum biradiatum. 18. Pediastrum duplex var. duplex. 19. Pediastrum duplex var. gracilimum. 20. Stauridium tetras. 21. Golenkiniopsis longispina. 22. Micractinium bornhemiense. 23. Micractinium bornhemiense (contraste de fase). 24. Micractinium pusillum. Barra $=10 \mu \mathrm{m}$.

Figures 13-24. Chlorophyceae of Billings and Guarapiranga Reservoirs. 13. Coelastrum reticulatum. 14. Acanthosphaera zachariasi. 15. Acanthosphaera zachariasi (phase contrast). 16. Monactinus simplex. 17. Parapediastrum biradiatum. 18. Pediastrum duplex var. duplex. 19. Pediastrum duplex var. gracilimum. 20. Stauridium tetras. 21. Golenkiniopsis longispina. 22. Micractinium bornhemiense. 23. Micractinium bornhemiense (phase contrast). 24. Micractinium pusillum. Bar $=10 \mu \mathrm{m}$. 
similares a Pediastrum tetras e incluiu-os no seu novo gênero Stauridium. O nome original Stauridium (Corda 1835) não foi considerado válido porque não havia descrição formal e nem espécie-tipo. Ainda de acordo com Buchheim et al. (2005), Stauridium foi validado posteriormente em 1839, pelo próprio Corda. Portanto, Stauridium foi proposto para acomodar o grupo monofilético formado por Pediastrum tetras e Pediastrum privum.

\section{MICRACTINIACEAE}

Golenkiniopsis Korshikov

Golenkiniopsis longispina (Korshikov) Korshikov, Protococcinae 5: 265. 1953. 三 Golenkinia longispina Korshikov, Proc. Chark. Stat. Univ. 10:129. 1937.
Figura 21

Células solitárias, esféricas, 7,0-9,5 $\mu$ m diâm., sem envelope mucilaginoso. Setas delicadas, longas, 6 a 9, distribuídas regularmente sobre a superfície celular, levemente flexuosas, afilando gradualmente em direção ao ápice, com as extremidades ligeiramente arqueadas, 38,0-46,0 $\mu \mathrm{m}$ compr. Cloroplasto único, parietal, com pirenóide esférico.

Material examinado: BRASIL. São PAULo: São Paulo, Represa Guarapiranga, 8-I-2004, Cetesb s.n. (SP391778), 25-III-2004, Cetesb s.n. (SP391779), 6-V-2004, Cetesb s.n. (SP399768), 15-VII-2004, Cetesb s.n. (SP399769), 23-IX-2004, Cetesb s.n. (SP399770); Represa Billings (Taquacetuba), 5-V-2004, Cetesb s.n. (SP399773).

Referências do táxon para as represas estudadas: Represa Billings (Carvalho 2003).

\section{Micractinium Fresenius}

Chave para identificação dos táxons encontrados nas represas Billings e Guarapiranga:

1. Células arranjadas em colônias piramidais Micractinium bornhemiense

1. Células arranjadas em colônias tetraédricas Micractinium pusillum

Micractinium bornhemiense (Conrad) Korshikov, Protococcineae 401. 1953. इ Errerella bornhemiensis Conrad, Bull. Soc. Bot. Belg. 52:242. 1913.

Figuras 22-23

Colônias piramidais, formadas por 12 ou 16 células. Células esféricas, 4,0-5,0 $\mu$ m diâm. Setas, 2 a 5, dispostas na margem livre das células, retas, longas, afilando gradualmente em direção ao ápice, 42,5-51,0 $\mu$ m compr. Cloroplasto único, poculiforme, com 1 pirenóide.

Material examinado: BRASIL. SÃo PaUlo: São Paulo, Represa Guarapiranga, 6-V-2004, Cetesb s.n. (SP399768).

Referências do táxon para as represas estudadas: Represa Billings (Sant’Anna 1984, Carvalho 2003).

Micractinium pusillum Fresenius, Abh. Senckenb. Natforsch. Ges. 2:236. 1858.

Figura 24

Colônias tetraédricas, formadas por 4 ou 8 células. Células esféricas, 5,0-6,0 $\mu \mathrm{m}$ diâm. Setas 4 a 6, retas, delicadas, longas, dispostas na margem livre das células e afilando gradualmente em direção ao ápice, 25,0-40,0 $\mu \mathrm{m}$ compr. Cloroplasto único, poculiforme, pirenóide não observado.

Material examinado: BRASIL. SÃo Paulo: São Paulo, Represa Guarapiranga, 8-I-2004, Cetesb s.n.
(SP391778), 25-III-2004, Cetesb s.n. (SP391779), 6-V-2004, Cetesb s.n. (SP399768), 15-VII-2004, Cetesb s.n. (SP399769), 23-IX-2004, Cetesb s.n. (SP399770), 18-XI-2004, Cetesb s.n. (SP399771); Represa Billings (Taquacetuba), 7-I-2004, Cetesb s.n. (SP399772), 5-V-2004, Cetesb s.n. (SP399773), 30-XI-2004, Cetesb s.n. (SP399775).

Referências do táxon para as represas estudadas: Represa Billings (Sant'Anna 1984, Xavier 1996, Carvalho 2003); Represa Guarapiranga (Beyruth 1996).

\section{OOCYSTACEAE}

\section{Eremosphaera De Bary}

Eremosphaera sp.

Figura 25-26

Células solitárias, esféricas, 23,0-32,0 $\mu \mathrm{m}$ diâm., parede celular espessa, lisa. Cloroplasto único, ramificado, pirenóides não observados.

Material examinado: BRASIL. São PAULO: São Paulo, Represa Guarapiranga, 25-III-2004, Cetesb s.n. (SP391779); 6-V-2004, Cetesb s.n. (SP399768); 15-VII-2004, Cetesb s.n. (SP399769); 23-IX-2004, Cetesb s.n. (SP399770); Represa Billings (Taquacetuba), 5-V-2004, Cetesb s.n. (SP399773).

Referências do táxon para as represas estudadas: primeira citação do gênero. 

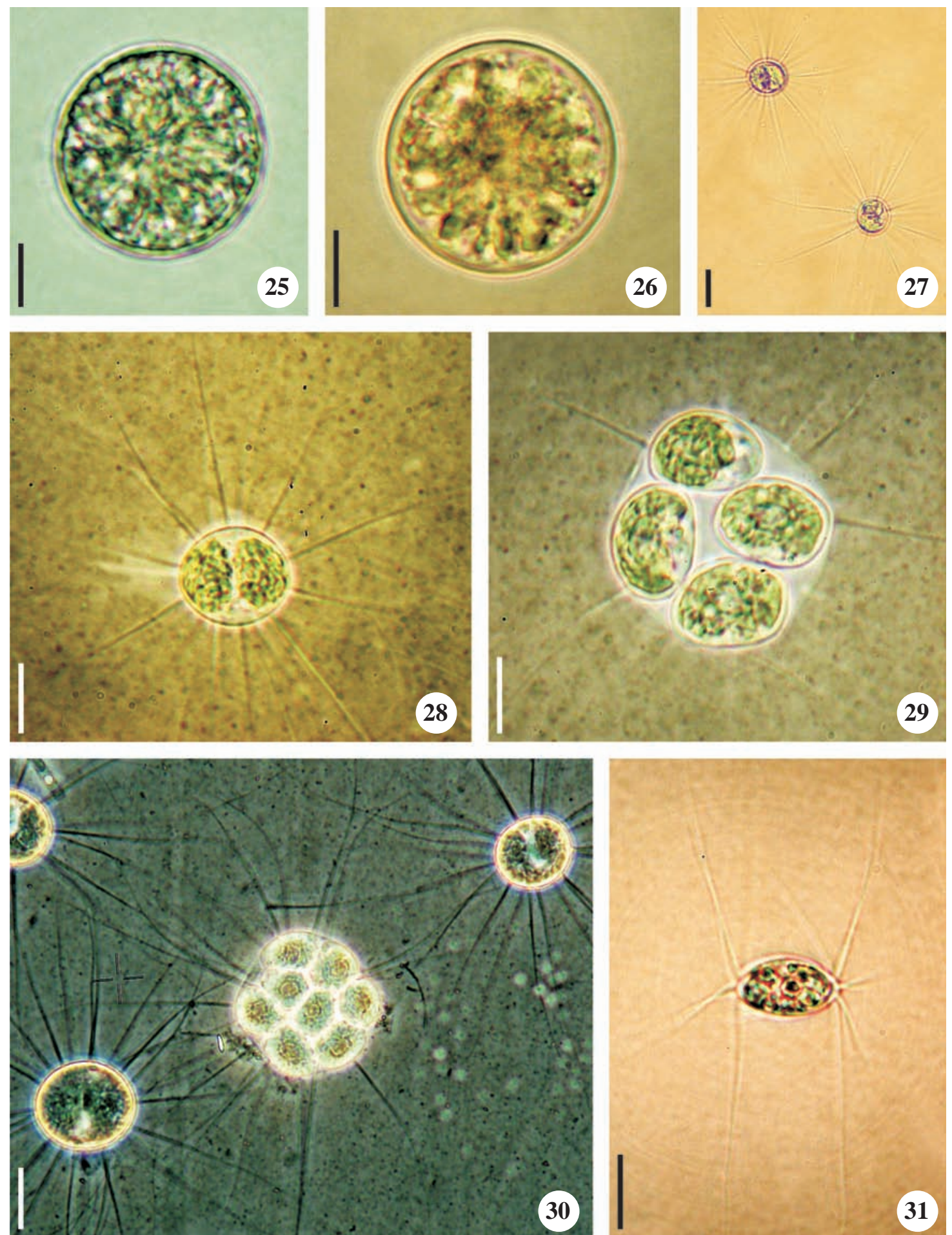

Figuras 25-31. Chlorophyceae das represas Billings e Guarapiranga. 25. Eremosphaera sp. 26. Eremosphaera sp. (adição de nanquim). 27. Franceia droescheri. 28. Franceia droescheri (adição de nanquim). 29. Franceia droescheri (estágio reprodutivo com 4 autósporos). 30. Franceia droescheri (estágio reprodutivo com 8 autósporos). 31. Lagerheimia longiseta. Barra $=10 \mu \mathrm{m}$.

Figures 25-31. Chlorophyceae of Billings and Guarapiranga Reservoirs. 25. Eremosphaera sp. 26. Eremosphaera sp. (china ink addition). 27. Franceia droescheri. 28. Franceia droescheri (china ink addition). 29. Franceia droescheri (reprodutive stage with 4 autospores). 30. Franceia droescheri (reprodutive stage with 8 autospores). 31. Lagerheimia longiseta. Bar $=10 \mu \mathrm{m}$. 
O material não pôde ser identificado com nenhuma espécie descrita do gênero, pois apresentou menor tamanho e os pirenóides não puderam ser observados.

\section{Franceia Lemmermann}

Franceia droescheri (Lemmermann) G. M. Smith, Freshwater algae of the United States: 505. 1933. $\equiv$ Chodatella droescheri Lemmermann, Ber. Dtsch. Bot. Ges. 18:98. 1900.

Figuras 27-30

Células solitárias, amplamente elípticas, 14,518,0 $\mu \mathrm{m}$ compr., 12,0-16,5 $\mu \mathrm{m}$ larg., sem envelope mucilaginoso. Numerosas setas, entre 20 e 25, distribuídas regularmente sobre a superfície celular, longas, delicadas, levemente espessadas na base e flexuosas, afilando gradualmente em direção ao ápice, 32,0-48,0 $\mu$ m compr. Dois cloroplastos parietais, em forma de calotas, voltados para a parte mediana da célula, com um pirenóide em cada um. Reprodução por 2, 4 ou 8 autósporos.

Material examinado: BRASIL. SÃo PAULO: São Paulo, Represa Guarapiranga, 8-I-2004, Cetesb s.n. (SP391778), 25-III-2004, Cetesb s.n.(SP391779), 15-VII-2004, Cetesb s.n. (SP399769), 23-IX-2004, Cetesb s.n. (SP399770), 18-XI-2004, Cetesb s.n. (SP399771); Represa Billings (Taquacetuba), 22-IX-2004, Cetesb s.n. (SP399774).

Referências do táxon para as represas estudadas: Represa Guarapiranga (Beyruth 1996).

Os indivíduos das populações analisadas diferiram da descrição original principalmente em relação ao comprimento maior das setas, que na descrição original varia de 9,0 a 32,0 $\mu$ m de comprimento. Particularmente na amostra de setembro da Represa Guarapiranga, a população de Franceia droescheri analisada encontrava-se em estágio reprodutivo, com indivíduos em auto-esporulação (figuras 29 e 30). Nesses casos, a forma celular mudou de elíptica para arredondada, as dimensões celulares aumentaram (25,0-40,0 $\mu \mathrm{m}$ larg.) e o número de setas foi menor em comparação com os indivíduos que não se encontravam em estágio reprodutivo. Os autósporos permanecem durante algum tempo no interior da célula parental alargada, até a sua liberação, que ocorre por rompimento da parede da célula-mãe.

\section{Lagerheimia Chodat}

Lagerheimia longiseta (Lemmermann) Printz, Vidensk. Skr. Kristiana 6:60. 1913. 三 Chodatella longiseta (Lemmermann), Hedwigia 37:310. 1898.

Figura 31

Células solitárias, elípticas, 11,0-14,0 $\mu \mathrm{m}$ compr., 5,5-8,0 $\mu \mathrm{m}$ larg.; pólos levemente atenuados. Cada pólo com 3 a 5 setas, longas, levemente flexuosas, afilando gradualmente em direção ao ápice, 38,0-46,0 $\mu$ m compr. Cloroplasto parietal, pirenóide não observado.

Material examinado: BRASIL. SÃo PAULO: São Paulo, Represa Guarapiranga, 6-V-2004, Cetesb s.n. (SP399768).

Referências do táxon para as represas estudadas: primeira referência.

\section{SCENEDESMACEAE}

\section{Crucigeniella Lemmermann}

Crucigeniella crucifera (Wolle) Komárek, Arch. Protistenkd.116:39. 1974. 三 Staurogenia crucifera Wolle, Bull. Torrey Bot. Club. 6:140. 1877.

Figura 32

Cenóbios planos, quadráticos, 12,0-14,0 $\mu$ m compr., 8,5-11,0 $\mu \mathrm{m}$ larg., formados por 4 células. Espaço losangular no centro da colônia. Células reniformes, 6,0-7,0 $\mu \mathrm{m}$ compr., 4,0-5,0 $\mu \mathrm{m}$ larg., parede celular espessada em um dos pólos. Cloroplasto único, parietal, pirenóide não observado.

Material examinado: BRASIL. São Paulo: São Paulo, Represa Guarapiranga, 6-V-2004, Cetesb s.n. (SP399768), 15-VII-2004, Cetesb s.n. (SP399769).

Referências do táxon para as represas estudadas: Represa Guarapiranga (Beyruth 1996).

\section{Desmodesmus An, Friedl \& Hegewald}

Chave para identificação dos táxons encontrados nas represas Billings e Guarapiranga:

1. Cenóbios formados por células dispostas alternadamente Desmodesmus denticulatus

1. Cenóbios formados por células dispostas linearmente

2. Espinhos dispostos obliquamente em apenas um dos ápices das células extremas

Desmodesmus armatus var. bicaudatus

2. Espinhos dispostos em ambos os ápices das células extremas

3. Células centrais em contato ao longo de todo seu comprimento Desmodesmus communis

3. Células centrais em contato em apenas $2 / 3$ do seu comprimento Desmodesmus opoliensis 
Desmodesmus armatus var. bicaudatus (Guglielmetti) Hegewald, Algolog. Stud. 96:4. 2000. 三 Scenedesmus acutiformis var. bicaudatus Guglielmetti, Nuova Notarisia, 21:31. 1910.

Figura 33

Cenóbios retos, planos, 25,5-27,0 $\mu \mathrm{m}$ compr., formados por 4 células dispostas linearmente. Células oblongas, 11,5-12,0 $\mu \mathrm{m}$ compr., 4,0-4,5 $\mu \mathrm{m}$ larg., com pólos arredondados. Células externas com um único espinho, em um dos pólos, de modo que o espinho de uma célula é diagonalmente oposto ao da outra, 7,5-9,0 $\mu \mathrm{m}$ compr. Células internas sem espinhos. Parede celular lisa. Cloroplasto único, parietal, com 1 pirenóide. Não há presença de costelas nas paredes.

Material examinado: BRASIL. SÃo PAULO: São Paulo, Represa Guarapiranga, 8-I-2004, Cetesb s.n. (SP391778), 25-III-2004, Cetesb s.n. (SP391779), 6-V-2004, Cetesb s.n. (SP399768); Represa Billings (Taquacetuba), 5-V-2004, Cetesb s.n. (SP399773).

Referências do táxon para as represas estudadas: Represa Billings (como Scenedesmus bicaudatus (Hansgirg) Chodat: Sant'Anna 1984, Xavier 1996, Carvalho 2003); Represa Guarapiranga (Beyruth 1996).

Os dados moleculares têm confirmado Scenedesmus e Desmodesmus como dois gêneros distintos pertencentes à família Scenedesmaceae (Johnson et al. 2007). Desmodesmus compreende os táxons com espinhos nas células extremas e/ou intermediárias do cenóbio e Scenedesmus envolve apenas os táxons sem espinhos no cenóbio. A maioria das novas combinações dos nomes específicos está no trabalho de Hegewald (2000).

Desmodesmus communis (Hegewald) Hegewald 2000, Algolog. Stud. 96:8. 2000. 三 Scenedesmus communis Hegewald, Algolog. Stud. 19:151. 1977.

Figura 34

Cenóbios retos, planos, 32,5-41,0 $\mu \mathrm{m}$ compr., formados por 4 células dispostas linearmente. Células internas oblongas, com pólos arredondados, 10,5-18,5 $\mu \mathrm{m}$ compr., 3,5-6,0 $\mu \mathrm{m}$ larg., sem ornamentação. Células externas trapezoidais, 10,0-18,0 $\mu \mathrm{m}$ compr., 3,5-7,0 $\mu \mathrm{m}$ larg., com margem externa levemente convexa, com um espinho longo em cada pólo, 10,0-17,0 $\mu \mathrm{m}$ compr. Parede celular lisa. Cloroplasto único, parietal, com 1 pirenóide.

Material examinado: BRASIL. SÃo PAULO: São Paulo, Represa Guarapiranga, 8-I-2004, Cetesb s.n. (SP391778), 25-III-2004, Cetesb s.n. (SP391779),
6-V-2004, Cetesb s.n. (SP399768), 15-VII-2004, Cetesb s.n. (SP399769), 23-IX-2004, Cetesb s.n. (SP399770), 18-XI-2004, Cetesb s.n. (SP399771); Represa Billings (Taquacetuba), 7-I-2004, Cetesb s.n. (SP399772), 5-V-2004, Cetesb s.n. (SP399773), 22-IX-2004, Cetesb s.n. (SP399774), 30-XI-2004, Cetesb s.n. (SP399775).

Referências do táxon para as represas estudadas: Represa Billings (como Scenedesmus quadricauda (Turpin) Brébrisson: Sant’Anna 1984, Xavier 1996, Carvalho 2003); Represa Guarapiranga (Beyruth 1996).

Desmodesmus denticulatus (Lagerheim) An et al., Algolog. Stud. 96:9. 2000. 三Scenedesmus denticulatus Lagerheim, Öfvers. K. Svensk. Vet. Akad. Förh. 39(2): 61.1882.

Figura 35

Cenóbios retos, planos, 20,5-22,0 $\mu \mathrm{m}$ compr., formados por 4 células dispostas alternadamente. Células internas ovaladas, $12,5-15,0 \mu \mathrm{m}$ compr., $6,5-8,0 \mu \mathrm{m}$ larg., sem ornamentações. Células externas elípticas, 11,0-12,5 $\mu \mathrm{m}$ compr., 5,5-6,0 $\mu \mathrm{m}$ larg., com 1 ou 2 espinhos curtos em cada pólo, 1,5-2,0 $\mu \mathrm{m}$ compr. Cloroplasto único, parietal, com 1 pirenóide.

Material examinado: BRASIL. São PAUlo: São Paulo, Represa Guarapiranga, 8-I-2004, Cetesb s.n. (SP391778), 25-III-2004, Cetesb s.n. (SP391779), 6-V-2004, Cetesb s.n. (SP399768), 15-VII-2004, Cetesb s.n. (SP399769), 23-IX-2004, Cetesb s.n. (SP399770), 18-XI-2004, Cetesb s.n. (SP399771); Represa Billings (Taquacetuba), 5-V-2004, Cetesb s.n. (SP399773).

Referências do táxon para as represas estudadas: Represa Billings (como Scenedesmus denticulatus Lagerheim: Sant'Anna 1984, Carvalho 2003); Represa Guarapiranga (Beyruth 1996).

Desmodesmus opoliensis (P. Richter) Hegewald, Algolog. Stud. 96:14. 2000. इ Scenedesmus opoliensis P.Richter, Z. Angew. Zool. 1:7.1895.

Figura 36

Cenóbios retos, planos, 49,5-54,5 $\mu \mathrm{m}$ compr., formados por 4 células dispostas linearmente. Células internas fusiformes, com pólos atenuados e arredondados, 20,5-22,0 $\mu \mathrm{m}$ compr., 7,0-8,0 $\mu \mathrm{m}$ larg., sem ornamentação. Células externas trapezoidais, 22,5-25,0 $\mu \mathrm{m}$ compr., 7,0-10,0 $\mu \mathrm{m}$ larg., com pólos truncados na base de inserção do espinho, margem externa levemente convexa, um espinho longo em cada pólo, 21,0-24,0 $\mu \mathrm{m}$ compr. Parede célular lisa. Cloroplasto único, parietal, com 1 pirenóide. 
Material examinado: BRASIL. São Paulo: São Paulo, Represa Guarapiranga, 8-I-2004, Cetesb s.n. (SP391778), 25-III-2004, Cetesb s.n. (SP391779), 6-V-2004, Cetesb s.n. (SP399768), 15-VII-2004, Cetesb s.n. (SP399769), 23-IX-2004, Cetesb s.n. (SP399770), 18-XI-2004, Cetesb s.n. (SP399771); Represa Billings
(Taquacetuba), 7-I-2004, Cetesb s.n. (SP399772), 5-V-2004, Cetesb s.n. (SP399773).

Referências do táxon para as represas estudadas: Represa Billings (como Scenedesmus opoliensis: Sant'Anna 1984, Carvalho 2003); Represa Guarapiranga (Beyruth 1996).

\section{Scenedesmus Meyen}

Chave para identificação dos táxons encontrados nas represas Billings e Guarapiranga:

1. Células dispostas em ziguezague Scenedesmus bernardii

1. Células dispostas linearmente

2. Células dispostas em uma única fileira

2. Células disposta em duas fileiras Scenedesmus acuminatus Scenedesmus disciformis

Scenedesmus acuminatus (Lagerheim) Chodat, Beitr. Kryptogamenflora Schweiz 1(3):211. 1902. इ Selenastrum acuminatum Lagerheim, Ofvers. K. Vetensk Akad. Förh. 39 (2):71.1882.

Figura 37

Cenóbios planos, 36,0-40,0 $\mu \mathrm{m}$ compr., formados por 4 células, dispostas linearmente. Células externas fusiformes, arcuadas, afilando em direção aos ápices, 23,5-28,0 $\mu \mathrm{m}$ compr., 5,0-6,5 $\mu \mathrm{m}$ larg. Células internas fusiformes, retas a levemente arcuadas, 29,0-34,0 $\mu \mathrm{m}$ compr., 4,0-5,5 $\mu \mathrm{m}$ larg. Parede celular lisa. Cloroplasto único, parietal, com 1 pirenóide.

Material examinado: BRASIL. SÃo PAULO: São Paulo, Represa Guarapiranga, 8-I-2004, Cetesb s.n. (SP391778), 25-III-2004, Cetesb s.n. (SP391779), 6-V-2004, Cetesb s.n. (SP399768), 15-VII-2004, Cetesb s.n. (SP399769), 23-IX-2004, Cetesb s.n. (SP399770), 18-XI-2004, Cetesb s.n. (SP399771); Represa Billings (Taquacetuba), 5-V-2004, Cetesb s.n. (SP399773), 22-IX-2004, Cetesb s.n. (SP399774), 30-XI-2004, Cetesb s.n. (SP399775).

Referências do táxon para as represas estudadas: Represa Billings (Sant'Anna 1984, Xavier 1996, Carvalho 2003); Represa Guarapiranga (Beyruth 1996).

Scenedesmus bernardii G.M.Smith, Trans. Wis. Acad. Sci. Arts Lett. 18(2):436-437. 1916.

Figura 38

Cenóbio planos, 75,0-90,0 $\mu$ m compr., formados por 8 células dispostas em ziguezague. Células fusiformes, as externas arcuadas e as internas apenas levemente arcuadas, afilando em direção aos ápices, 37,0-46,0 $\mu \mathrm{m}$ compr., 6,0-8,0 $\mu \mathrm{m}$ larg. Um dos pólos de cada célula interna une-se à região mediana convexa da célula vizinha. Cloroplasto único, parietal, com 1 pirenóide.
Material examinado:BRASIL. SÃoPAULO: São Paulo, Represa Guarapiranga, 8-I-2004, Cetesb s.n. (SP391778), 6-V-2004, Cetesb s.n. (SP399768), 15-VII-2004, Cetesb s.n. (SP399769), 23-IX-2004, Cetesb s.n. (SP399770), 18-XI-2004, Cetesb s.n. (SP399771); Represa Billings (Taquacetuba), 5-V-2004, Cetesb s.n. (SP399773), 30-XI-2004, Cetesb s.n. (SP399775).

Referências do táxon para as represas estudadas: Represa Billings (como Scenedesmus javanensis Chodat: Xavier 1996); Represa Guarapiranga (Beyruth 1996).

Scenedesmus disciformis (Chodat) Fott \& Komárek, Preslia 32:129. 1960. $\equiv$ Scenedesmus bijugatus var. disciformis Chodat, Algol. Vert. Suiss. 213. 1902.

Figura 39

Cenóbios planos, 21,0-24,5 $\mu \mathrm{m}$ compr., formados por 8 células dispostas linearmente em 2 fileiras, alternadas, espaços intercelulares ausentes. Células marginais um pouco deslocadas para cima ou para baixo. Células oblongas, levemente côncavas, 9,5-10,5 $\mu \mathrm{m}$ compr., 4,5-5,0 $\mu \mathrm{m}$ larg. Parede celular lisa. Cloroplasto único, parietal, com 1 pirenóide.

Material examinado: BRASIL. SÃo PAULO: São Paulo, Represa Billings (Taquacetuba), 5-V-2004, Cetesb s.n. (SP399773), 30-XI-2004, Cetesb s.n. (SP399775).

Referências do táxon para as represas estudadas: primeira referência.

\section{Tetrastrum Chodat}

Tetrastrum homoiacanthum (Huber-Pestalozzi) Comas, Acta Bot. Cuba 17:22. 1984. 三 Tetrastrum heteracanthum var. homoiacanthum Huber-Pestalozzi, Arch. Hydrobiol. 20:423. 1929.

Figura 40

Cenóbios planos, quadrangulares, 21,0-22,5 $\mu \mathrm{m}$ compr. (com espinhos), formados por 4 células dispostas 

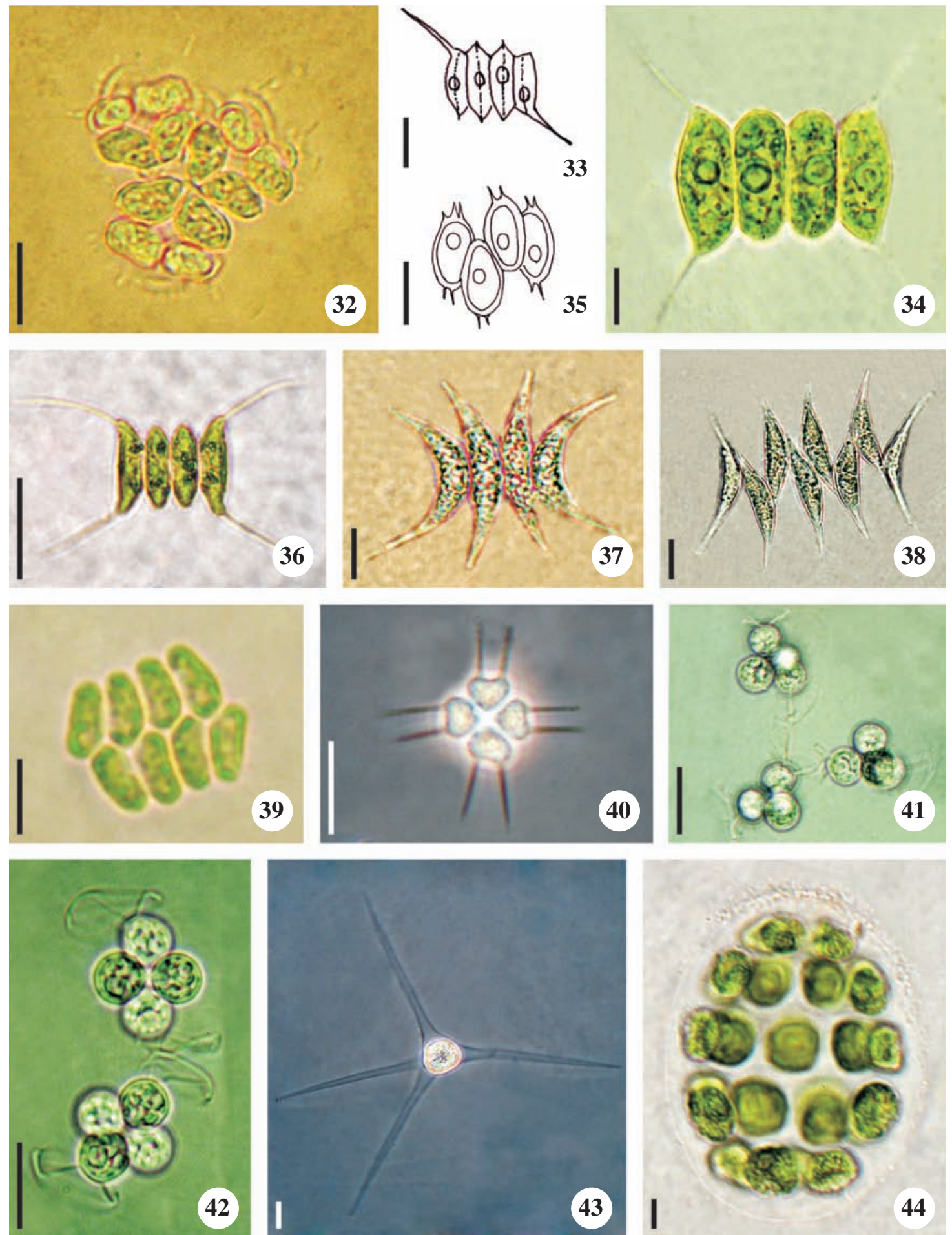

Figuras 32-44. Chlorophyceae das represas Billings e Guarapiranga. 32. Crucigeniella crucifera. 33. Desmodesmus armatus var. bicaudatus. 34. Desmodesmus communis. 35. Desmodesmus denticulatus. 36. Desmodesmus opoliensis. 37. Scenedesmus acuminatus. 38. Scenedesmus bernardii. 39. Scenedesmus disciformis. 40. Tetrastrum homoiacanthum (contraste de fase). 41-42. Westella botryoides. 43. Treubaria crassispina (contraste de fase). 44. Eudorina illinoisensis. Barra $=10 \mu \mathrm{m}$.

Figures 32-44. Chlorophyceae of Billings and Guarapiranga Reservoirs. 32. Crucigeniella crucifera. 33. Desmodesmus armatus var. bicaudatus. 34. Desmodesmus communis. 35. Desmodesmus denticulatus. 36. Desmodesmus opoliensis. 37. Scenedesmus acuminatus. 38. Scenedesmus bernardii. 39. Scenedesmus disciformis. 40. Tetrastrum homoiacanthum (phase contrast). 41-42. Westella botryoides. 43. Treubaria crassispina (phase contrast). 44. Eudorina illinoisensis. Bar $=10 \mu \mathrm{m}$. 
cruciadamente, com pequeno espaço intercelular quadrangular. Células cordiformes, ângulos arredondados, 3,0-3,5 $\mu$ m compr., 4,0-4,5 $\mu \mathrm{m}$ larg., margem externa reta, com 2 espinhos retos, iguais, dispostos excentricamente, 6,0-7,0 $\mu$ m compr. Cloroplasto único, parietal, pirenóide não observado.

Material examinado: BRASIL. SÃo PAULO: São Paulo, Represa Billings (Taquacetuba), 5-V-2004, Cetesb s.n. (SP399773).

Referências do táxon para as represas estudadas: primeira referência.

\section{Westella de Wildeman}

Westella botryoides (W. West) de Wildeman, Bull. Herb. Boissier 5 (6): 532. 1897. 三 Tetracoccus botryoides W. West, J. R. Microsc. Soc. 1892:735. 1892.

Figuras 41-42

Cenóbios quadrangulares, 9,5-14,5 $\mu \mathrm{m}$ compr., formados por 4 células dispostas cruciadamente, com espaço intercelular retangular. Restos de parede da célula parental unindo os cenóbios na forma de fios de mucilagem densos. Células esféricas, 5,0-7,0 $\mu \mathrm{m}$ diâm. Cloroplasto único, poculiforme, pirenóide não observado.

Material examinado: BRASIL. São PAULo: São Paulo, Represa Guarapiranga, 6-V-2004, Cetesb s.n. (SP399768), 15-VII-2004, Cetesb s.n. (SP399769); Represa Billings (Taquacetuba), 5-V-2004, Cetesb s.n. (SP399773).

Referências do táxon para as represas estudadas: Represa Billings (Carvalho 2003); Represa Guarapiranga (Beyruth 1996).

\section{TREUBARIACEAE}

\section{Treubaria Bernard}

Treubaria crassispina G. M. Smith, Trans. Am. Microsc. Soc. 45:178. 1926.

Figura 43

Células solitárias, tetraédricas, protoplasma arredondado, 12,0-14,0 ㅆm diâm., justaposto à parede celular, ângulos arredondados, lados levemente convexos a quase retos. Células com quatro espinhos hialinos, cônicos, partindo da região central e afilando gradualmente em direção aos ápices agudos, 46,0-58,0 $\mu \mathrm{m}$ compr. Cloroplasto único, parietal, com 1 pirenóide.

Material examinado: BRASIL. SÃo PAULO: São Paulo, Represa Guarapiranga, 6-V-2004, Cetesb s.n. (SP399768).
Referências do táxon para as represas estudadas: primeira referência.

\section{VOLVOCALES}

\section{VOLVOCACEAE}

\section{Eudorina Ehrenberg}

Eudorina illinoisensis (Kofoid) Pascher, Susswasser Fl. Deutschl. 4:443. 1927. झPleodorina illinoisensis Kofoid, Bull. Ill. St. Lab. Nat. Hist. 5:273. 1898.

Figura 44

Colônias vegetativas, elipsoidais, 85,0-105,0 $\mu \mathrm{m}$ compr., 57,5-78,0 $\mu \mathrm{m}$ larg., pólo anterior e posterior arredondados. Envoltório mucilaginoso comum, duplo. Colônias com 32 células arredondadas em vista lateral e apical, bainha de mucilagem individual hexagonal, tamanhos desiguais, sendo que as 4 células da série anterior são menores, 9,5-10,5 $\mu \mathrm{m}$ diâm. e as demais células das séries posteriores maiores, 13,0-14,5 um diâm., arranjadas regularmente em 5 séries paralelas distintas de 4-8-8-8-4 células. Cada célula com dois flagelos apicais de tamanhos iguais. Estigma arredondado, localizado na região anterior da célula, maior na série anterior, tamanho reduzido nas séries posteriores e geralmente ausente na última série. Cloroplasto único, poculiforme, com 3 a 5 pirenóides.

Material examinado: BRASIL. SÃo PAULO: São Paulo, Represa Guarapiranga, 8-I-2004, Cetesb s.n. (SP391778); 25-III-2004, Cetesb s.n. (SP391779).

Referências do táxon para as represas estudadas: primeira referência.

A classe Chlorophyceae apresentou 33 táxons para a represa Guarapiranga e 28 táxons para a represa Billings. O gênero Desmodesmus apresentou maior riqueza de espécies (quatro), seguido de Ankistrodesmus e Scenedesmus (três espécies cada). Oito táxons foram exclusivos da represa Guarapiranga: Acanthosphaera zachariasi, Ankistrodesmus bibraianus, Crucigeniella crucifera, Lagerheimia longiseta, Micractinium bornhemiense, Monoraphidium arcuatum, Treubaria crassipina e Eudorina illinoisensis. Três táxons foram exclusivos da represa Billings: Botryococcus terribilis, Tetrastrum homoiacanthum e Scenedesmus disciformis. Portanto, a grande maioria das espécies de clorofíceas (70\%) foi comum aos dois reservatórios.

Tomando como base os trabalhos de Beyruth (1996), para a Guarapiranga, e Carvalho (2003), para a Billings, mesmo considerando que foram feitos 
em épocas distintas e com amostragens diferentes, observa-se que as espécies de clorofíceas comuns às duas represas constituíam cerca de $20 \%$ do total desta classe para ambas as represas. Assim, o aumento que verificamos na porcentagem de semelhança (20\% para $70 \%$ ) entre a biodiversidade de clorofíceas dessas duas represas, parece indicar que a transposição de água do Braço Taquacetuba (Billings) para a Guarapiranga, desde 2000, está contribuindo para uniformizar a composição fitoplanctônica destes corpos de água. Este fato é preocupante pois outros trabalhos (Carvalho et al. 2007, Matsuzaki 2007, Gemelgo et al. 2008) já mencionam o aumento da riqueza e da densidade da comunidade fitplanctônica, sobretudo das cianobactérias, na represa Guarapiranga o que traz várias consequências para o meio ambiente e saúde pública.

\section{Referências bibliográficas}

BEYRUTH, Z. 1996. Comunidade fitoplanctônica da Represa de Guarapiranga: 1991-1992. Aspectos ecológicos, sanitários e subsídios para reabilitação da qualidade ambiental. Tese de doutorado, Universidade de São Paulo, São Paulo.

BUCHHEIM, M., BUCHHEIM, J., CARLSON, T., BRABAND, A., HEPPERLE, D., KRIENITZ, L, HEGEWALD, E. \& WOLF, M. 2005. Phylogeny of the Hydrodictyaceae (Chlorophyceae): inferences from rDNA data. Journal Phycology 41:1039-1054.

CARVALHO, L.R., SANT'ANNA, C.L., GEMELGO, M.C.P. \& AZEVEDO, M.T.P. 2007. Cyanobacterial occurrence and detection of microcystin by planar chromatography in surface water of Billings and Guarapiranga Reservoirs, SP, Brazil. Revista Brasileira de Botânica 30:141-148.

CARVALHO, M.C. 2003. Comunidade fitoplanctônica como instrumento de biomonitoramento de reservatórios no Estado de São Paulo. Tese de doutorado, Universidade de São Paulo, São Paulo.

CETESB. 2002. Relatório de qualidade das águas interiores do Estado de São Paulo, 2001. Companhia de Tecnologia de Saneamento Ambiental - Cetesb, São Paulo.

CORDA, A.J.C. 1835. Obsevations sur les animalcules microscopiques, qu'on trouve auprès des eaux thermales de Carlsbad. Almanach de Carlsbad 5:166-211.

CORDA, A.J.C. 1839. Observations sur les Euastrées et les Cosmariées. Almanach de Carlsbad 9:213-246.

GEMELGO, M.C.P., SANT’ANNA, C.L., TUCCI, A. \& BARBOSA, H.R. 2008. Population dynamics of Cylindrospermopsis raciborskii (Woloszynska) Seenayya \& Subba Raju, a cyanobacteria toxic species, in water supply reservoirs in São Paulo, Brazil. Hoehnea 35:297-307.
HEGEWALD, E. 2000. New combinations in the genus Desmodesmus (Chlorophyceae, Scenedesmaceae). Algological Studies 96:1-18.

HENRY, R., NUNES, M.A., MITSUKA, P.M., LIMA, N. DE \& CASANOVA, S.M.C. 1998. Variação espacial e temporal da produtividade primária pelo fitoplâncton na Represa de Jurumirim (Rio Paranapanema, SP). Revista Brasileira de Biologia 58:571-590.

HINDÁK, F. 1980. Studies on the chlorococcal algae (Chlorococcales) II. Biologické Pracé 26:1-195.

HUBER-PESTALOZZI, G. 1961. Chlorophyceae (Grünalgen) Ordnung: Volvocales. In Das Phytoplankton des Süsswassers. Teil 5. (A. Thienemann, ed.). E. Schweizerbartsche Verlagsbuchhandlung, Stuttgart.

ISA - Instituto Socioambiental. 2006. Guarapiranga 2005: como e por que São Paulo está perdendo este manancial. Resultados do Diagnóstico Socioambiental participativo da bacia Hidrográfica da Guarapiranga (M. Whately \& P.M. Cunha, orgs.). Instituto Socioambiental - ISA, São Paulo.

JOHNSON, J.L., FAWLEY, M.W. \& FAWLEY, K.P. 2007. The diversity of Scenedesmus and Desmodesmus (Chlorophyceae) in Itasca State Park, Minnesota, USA. Phycologia 46:214-229.

KLEEREKOPER, H. 1937. Biologia da Represa Velha de Santo Amaro (Represa Guarapiranga). Revista do Departamento de Água e Esgoto 1:151-161.

KLEEREKOPER, H. 1939. Estudo limnológico da Represa de Santo Amaro. Boletim da Faculdade de Filosofia e Ciências da Universidade de São Paulo 17:1-151.

KOMÁREK, J. \& FOTT, B. 1983. Chlorophyceae(Grünalgen), Ordung: Chlorococcales. In Süsswassersflora, Band 1. (G. Huber Pestallozi, H. Heynig \& D. Mollenhauer, eds.). Gustav Fischer, Jena, p.1-1044.

KOMÁREK, J. \& MARVAN, P. 1992. Morphological diferences in natural populations of the genus Botryococcus (Chlorophyceae). Archiv Protistenk 141:65-100.

MATSUZAKI, M. 2007. Transposição das águas do braço Taquacetuba da Represa Billings para a Represa Guarapiranga: aspectos relacionados à qualidade de água para abastecimento. Tese de doutorado, Universidade de São Paulo, São Paulo.

PALMER, C.M. 1960. Algas e suprimento de água na área de São Paulo. Revista do Departamento de Água e Esgoto 21:11-15.

ROCHA, A.A. 1976. Limnologia, os aspectos ecológicos e sanitários e a macrofauna bentônica da represa Guarapiranga na RMSP. Tese de doutorado, Universidade de São Paulo, São Paulo.

SANT'ANNA, C.L. 1984. Chlorococcales (Chlorophyceae) do Estado de São Paulo, Brasil. Bibliotheca Phycologica 67:1-348. 
SANT'ANNA, C.L., AZEVEDO, M.T.P., WERNER, W.R., DOGO, C.R., RIOS, F.R., \& CARVALHO, L.R. 2008. Review of toxic species of cyanobacteria in Brazil. Algological Studies 126:249-263.

TUCCI, A., SANT'ANNA, C.L., GENTIL, R.C. \& AZEVEDO, M.T.P. 2006. Fitoplâncton do Lago das Garças, São Paulo, Brasil: um reservatório urbano eutrófico. Hoehnea 33:1-29.
XAVIER, M.B. 1979. Contribuição ao estudo da variação sazonal do fitoplâncton na Represa Billings, São Paulo. Dissertação de mestrado, Universidade de São Paulo, São Paulo.

XAVIER, M.B. 1996. Fitoplâncton do Rio Grande, Represa Billings, São Paulo, Brasil: estudo taxonômico. Iheringia 47:103-112. 